\title{
The Effect of Visual Experience on Development of NMDA Receptor Synaptic Transmission in Kitten Visual Cortex
}

\author{
Kevin Fox, ${ }^{1}$ Nigel Daw, ${ }^{2}$ Hiromichi Sato, ${ }^{3}$ and Damian Czepita ${ }^{2}$ \\ 'Section of Neurobiology and Center for Neural Science, Brown University, Providence, Rhode Island 02912, ${ }^{2}$ Department \\ of Anatomy and Neurobiology, Washington University School of Medicine, St. Louis, Missouri 63112, and ${ }^{3}$ Department of \\ Neurophysiology, Biomedical Research Center, Osaka University Medical School, Suita, Osaka 565, Japan
}

We have studied the effect of dark rearing on the development of excitatory amino acid transmission in 6-week-old kittens. In normal kittens, the NMDA component of the visual response decreases between 3 and 6 weeks of age for cells located in layers IV, V, and VI (Fox et al., 1991). Dark rearing to 6 weeks of age prevents this decrease. Subsequent exposure to light allows the decrease to proceed. Ten days in the light after 6 weeks in the dark was sufficient to decrease the NMDA component of the visual response to the same levels seen in light-reared animals of the same age. Comparison of the effect of the non-NMDA antagonist 6-cyano7-dinitroquinoxaline-2,3-dione with the NMDA antagonist aminophosphonovalerate showed that the changes were due to the relative contributions of NMDA and non-NMDA receptors to the visual response rather than the overall contribution of glutamate receptors.

We also studied the receptive field properties of the cells in the various groups of kittens. Cells given $4 \mathrm{~d}$ in the light after 6 weeks in the dark showed increased direction selectivity but little change in response firing rate. After $10 \mathrm{~d}$ in the light, visual responses did show some recovery toward adult values, but neither average firing rates nor the proportion of direction-selective cells reached the levels found in normal 6-week-old animals, contrary to the suggestion that a short period in the light can reverse the effect of dark rearing completely.

These results show that the decrease in the NMDA component of the visual response seen during normal development of the cortex is caused by visual experience. Changes in NMDA receptors and developmental events such as geniculocortical afferent segregation and acquisition of orientation tuning covary as a function of visual experience rather than age, strongly suggesting that NMDA receptors are involved in experience-dependent developmental processes.

Visual information appcars to be transmittcd by cxcitatory amino acid (EAA) synapses in area 17 (Tsumoto, 1990). EAAs activate cells via both NMDA and non-NMDA receptors. However, the NMDA component of the visual response is greater

\footnotetext{
Received Aug. 26, 1991; revised Jan. 23, 1992; accepted Feb. 11, 1992.

This work was supported by NIH Grants NS 27759 (to K.F) and EY 00053 (to N.D). We are grateful to Jim Peters and Paula Krueger for technical assistance and to Barbara Gordon and Andreas Burkhalter for criticism of the manuscript.

Correspondence should be addressed to Dr. K. Fox, Department of Physiology, 6-255 Millard Hall, University of Minnesota, Minneapolis, MN 55455.

Copyright (c) 1992 Society for Neuroscience $0270-6474 / 92 / 122672-13 \$ 05.00 / 0$
}

for cells in cortical layers IV, V, and VI of kittens than adults (Fox et al., 1989, 1990), which may be partly attributable to a decrease in the number of NMDA receptors in these layers with increasing age (Bode-Greuel and Singer, 1989; Gordon et al., 1991; Reynolds and Bear, 1991).

Many aspects of receptive field development are dependent on visual experience rather than the absolute age of the animal (see Mitchell and Timney, 1984). It is unknown whether the physiological decrease in NMDA receptor function is related to the absolute age of the animal or whether it is dependent on the developmental stage the cortex has reached. The developmental event that appears most closely correlated with the decrease of NMDA receptor function is segregation of geniculocortical afferents in layer IV of the cortex (Fox et al., 1989; Daw and Fox, 1991). There is precedence for thinking that NMDA receptors are critically involved in segregation of afferents because the NMDA antagonists D-aminophosphonovalerate (D-APV) and MK-801 prevent retinal afferents from segregating and the agonist NMDA promotes segregation in the frog tectum (Cline and Constantine-Paton, 1990; Cline et al., 1987). However, testing for a causal link between NMDA receptors and segregation of afferents into ocular dominance patches in the cat visual cortex is problematic. In theory, one could block NMDA receptors and test whether segregation was prevented; in practice, blocking NMDA receptors by infusion of D-APV causes a reduction of visual responses in cortical cells (Miller et al., 1989), and visual responses are known to be essential for segregation anyway (Stryker and Harris, 1986). This fact prevents unambiguous interpretation of the results of D-APV infusion cxpcriments.

Our strategy has been, therefore, to use a procedure that alters segregation to examine NMDA receptor function, rather than to block NMDA receptor function and examine segregation. Dark rearing is known to prevent (Swindale, 1981, 1988; Mower et al., 1985) or at least delay (Stryker and Harris, 1986) segregation of geniculocortical afferents in area 17 . Provided that the animals are not dark reared for longer than about 6 weeks, the afferents retain the capacity for segregation on exposure to the light (Swindale, 1988). If NMDA receptors are necessary for segregation, they must be active functionally in animals dark reared to 6 weeks of age, even though they are not in animals reared in the light to 6 weeks of age; this was the first hypothesis we tested. The second hypothesis was that NMDA receptor function should decrease in visual cortex, in concert with segregation, irrespective of when the normal rate of segregation commenced. Segregation requires about $128 \mathrm{hr}$ exposure to the light in dark-reared (DR) animals (Swindale, 1988). We there- 
fore assayed NMDA receptor function in animals dark reared for 6 weeks and then brought out into the light for 4 or $10 \mathrm{~d}$.

\section{Materials and Methods}

Subjects. Recordings were made from four groups of animals: seven animals reared in the light until the day of recording (age range, 42-53 d), six animals reared in complete darkness for 6 weeks $(43-49$ d), four animals reared in the dark until 6 weeks of age $(43-49$ d) and then brought into the light for $4 \mathrm{~d}$, and five animals reared in the dark for 6 weeks $(42-45 \mathrm{~d})$ and then brought into the light for $10 \mathrm{~d}$.

Rearing conditions. Eight litters were reared in light-tight cages in a darkened room starting at 4-5 d postpartum until $42-49 \mathrm{~d}$. The specially designed cages were found to be light tight from preliminary tests where unexposed film was placed inside the cages. Infrared viewers allowed us to see in the dark during daily changes of litter trays, food, and water and allowed routine checks on the general condition of the animals. It was clear from daily monitoring and from the condition of the animals when they were brought into the light that they maintained excellent health in the dark. As each kitten from the litter was introduced to the light at the end of dark rearing, it was housed with its mother to increase visual stimulation and decrease stress.

All rearing procedures were reviewed and approved by the animal care committee of Washington University Medical School.

Surgery. The general methods of surgical preparation used here have been described in detail in previous publications (Fox et al., 1989, 1990). Briefly, animals were sedated with Acepromazine, $0.46 \mathrm{mg} / \mathrm{kg}$ body weight (Aveco, Fort Dodge, IA), and given a preanesthetic dose of atropine $(0.5 \mathrm{mg} / \mathrm{kg})$. Anesthesia was induced with $4 \%$ halothane in a mixture of $67 \%$ nitrous oxide and $33 \%$ oxygen, and maintained after surgery with $0.7-1 \%$ halothane in the same gas mixture. All wound margins and pressure points were treated with local anesthetic (Lidocaine). After surgery, the animal was paralyzed by intravenous infusion of pancuronium bromide at $0.6-1.5 \mathrm{mg} / \mathrm{hr}$ (Pavulon, Organon Diagnostics, $\mathrm{NJ}$ ). Heart rate and expired $\mathrm{CO}_{2}$ were continuously monitored, $\mathrm{CO}_{2}$ being maintained between $3.0 \%$ and $4.2 \%$.

Animals that were purely dark reared were sedated with Acepromazine (AVCO, Fort Dodge, IA) before being removed from the dark on the day of the recording. Animals were transported in a dark box before anesthesia was induced. The period of unanesthetized light exposure was less than 5 or $10 \mathrm{~min}$ on the day of the experiment. Since it takes approximately $128 \mathrm{hr}$ of light exposure to produce segregation (Swindale, 1988), this short exposure is unlikely to have affected our results. The experiments usually lasted $16 \mathrm{hr}$ or so, but since anesthesia prevents plasticity in visual cortex (Freeman and Bonds, 1979), little change was expected or observed.

Electrodes and recordings. Three-barrel carbon fiber microelectrodes were constructed as described previously (Armstrong-James et al., 1980; Fox et al., 1990).

Single-unit recordings were made from all layers, and each recording location was marked with a small focal lesion $(2 \mu \mathrm{A}, 10 \mathrm{sec}$, tip negative). Neurons were sampled at approximately $300 \mu \mathrm{m}$ intervals throughout the penetration. After moving the electrode to a new position, a handheld projector was used to stimulate the receptive field. If the recording isolation was inadequate, the electrode was advanced in small $(20 \mu \mathrm{m})$ steps until an improvement was found. Receptive fields were characterized and plotted on a tangent screen.

Visual stimuli were applied by an optical bench under computer control. Spikes were discriminated through a voltage window and monitored for amplitude and time course on a digital storage oscilloscope (Hameg HM208, Port Washington, NY). Spike discharge times were recorded relative to the stimulus position, via an 80286-based microcomputer (PC's Ltd.), using a Datalab data acquisition board (Tecmar, Cleveland, $\mathrm{OH}$ ). Peristimulus time histograms were displayed on line, enabling us to monitor response stability. Spike times were stored on hard disk for subsequent off-line analysis using custom-written ASYST programs (Asyst Software Inc., Rochester, NY). Spike times were recorded for all experiments, allowing us to analyze data off line in several different ways.

Visual stimulus. The computer-controlled visual stimulus was a moving bar of light swept across the receptive field. The optimal direction, velocity, length, and width of the stimulus were determined and used to stimulate the cell via the dominant eye. One second of spontaneous activity was recorded before the start of each stimulus traverse. After moving through the receptive field in one direction, the light bar paused for $1 \mathrm{sec}$ beyond the receptive field before sweeping back in the reverse direction.

Iontophoresis. All drugs were dissolved in distilled water at the following concentrations: NMDA, $20 \mathrm{mM}$; D-APV, $50 \mathrm{~mm}$; 6-cyano-7dinitroquinoxaline-2,3-dione (CNQX), $20 \mathrm{~mm}$ (Tocris, Bristol, UK); all adjusted to $\mathrm{pH} 7.4-8.0$ except $\mathrm{CNQX}(\mathrm{pH} 8.5)$. Effective retain currents were typically 3-6 $\mathrm{nA}$ with these electrodes, or $10-15 \mathrm{nA}$ in the case of CNQX.

The effect of D-APV was tested by applying an ejecting current of 20 $\mathrm{nA}$ for $1 \mathrm{~min}$ followed by $10 \mathrm{nA}$ for 2 min during continued stimulus presentations. With these electrodes, $20 \mathrm{nA}$ ejecting current has been found to yicld NMDA-specific antagonism when applied for approximately 4 min (Fox et al., 1989).

Analysis of data. A detailed description of the general methods of data analysis can be found in earlier publications (Fox et al., 1989, 1990). Firing rates were averaged over the entire response duration for one direction of stimulus presentation (typically $1-2 \mathrm{sec}$ ). Visual responses were expressed as average firing rate during the response minus spontaneous activity. The firing rate for the best direction was taken to construct histograms of firing rates for populations of cells.

Drug trials were included in the analysis if the coefficient of variation (standard deviation/mean) for sequential control visual responses was 0.2 or less. The effects of antagonists were estimated by comparing the average visual response during the second and third minute of drug application to the average response during 5-6 min of preceding control data. Effects were judged significant if the visual response was less during antagonist application at the $p<0.05$ level (by $t$ test) and the cell's average response returned to within $75 \%$ of control values within 15 min of ceasing antagonist application. Effects were considered insignificant at $p \geq 0.1$. In all cases, D-APV was tested at least twice on each cell. Results were discarded if sequential tests with D-APV gave widely differing results (i.e., results differing by more than $20 \%$ of control). These methods allowed classification of the cells into two groups, cells affected and cells unaffected by D-APV (see Fig. 5).

To estimate the significance of differences in the effect of D-APV on visual responses across different rearing conditions, the means of the populations were compared in the usual way by the use of a $t$ test. A two-factor analysis of variance was also applied to the same data, as described in the text, the factors being rearing condition of the animal and layer location of the cell. To compare the distributions of response firing rates under different rearing conditions, a Mann-Whitney $U$ test was used. For cases where both samples exceeded 10 observations, this involves using the $z$ test, which applied to all uses of the Mann-Whitney $U$ test described here. Finally, $\chi^{2}$ statistics were used to compare changes in direction selectivity across rearing conditions. Note that all expressions of the form $x \pm y$ in the text represent mean \pm standard deviation.

The index used to describe the overall effect of D-APV in each layer (see Fig. 6) was calculated by averaging the decrease in response for all the cells in a given layer and subtracting the result from unity; that is,

$$
\begin{aligned}
& \text { NMDA component } \\
& \text { for } N \text { cells }
\end{aligned}=1-\left(\sum_{n=1}^{N}\left[\frac{\text { response during APV }}{\text { control response }}\right]_{n}\right) N^{-1} \text {. }
$$

In order to describe the distribution of the ocular dominance histogram, we calculated two commonly used indices: the weighted ocular dominance (WOD), which was calculated as

$$
\mathrm{WOD}=\frac{\mathrm{G} 2+2 \mathrm{G} 3+3 \mathrm{G} 4+4 \mathrm{G} 5+5 \mathrm{G} 6+6 \mathrm{G} 7}{6 N},
$$

where $N$ is the total number of cells; group $1(\mathrm{Gl})$ is the number of cells driven solely by the contralateral eye; $G 7$, solely by the ipsilateral eye; and G2-G6, degrees of binocularity in between, G4 being the number of cells driven equally by both eyes. A value of 0 indicates that all cells only respond to the contralateral eye and a value of 1 , only to the ipsilateral eye. The other index was the binocularity index (BI) and was calculated as

$$
\mathrm{BI}=\frac{[\mathrm{G} 2+\mathrm{G} 6]+2[\mathrm{G} 3+\mathrm{G} 5]+3 \mathrm{G} 4}{3 N} .
$$

This value varies between 0 and 1 , with 0 indicating that all cells are monocular (without regard to whether they are ipsilateral or contralateral) and 1 indicating all cells are driven equally by both eyes.

Cells were classified into one of four direction spccificity groups by testing their visual responses to movement of a bar of light of optimal length and width moved through the receptive field at the optimal 
Table 1. Summary of the effect of D-APV on the visual responses of cells recorded in LR ana $\overline{D R}$ animals versus layer

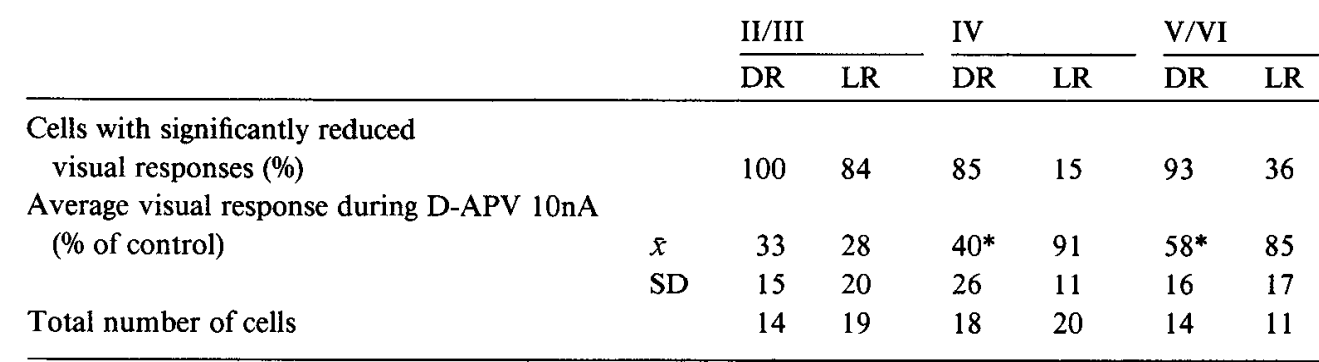

Asterisk indicates significant at the $p<0.001$ level (two-tailed $t$ test). Average reductions are calculated using all cells in a layer.

velocity. Unidircctional cells were those exhibiting no response to a stimulus in the opposite direction to the optimal or at least greater than a 3:1 ratio between forward and reverse directions. Bidirectional cells were tuned to a particular direction of motion but showed responses both to forward and reverse motion. Bidirectional cells were split into two groups dependent on their width of tuning: "bidirectional" cells, which only had responses over a range less than or equal to $45^{\circ}$ either side of optimal, and "widely tuned" cells, which had some response to stimulus directions greater than $45^{\circ}$ either side of the optimal direction. Widely tuned cells still showed a clear null direction at which no response could be elicited. Omnidirectional cells were those that showed responses to all directions of stimulus presentation.

Lesions and histology. Small focal lesions were made with the recording electrode using $2 \mu \mathrm{A}$ DC for $10 \mathrm{sec}$ (tip negative). Lesions were usually $50-100 \mu \mathrm{m}$ diameter and characterized by gliosis. Higher currents of 3-3.5 $\mu \mathrm{A}$ were used for lesions made within $3 \mathrm{hr}$ of perfusion, as gliosis was reduced in these cases. On completion of the experiment, the animal was deeply anesthetized before transcardiac perfusion. An injection of heparin preceded $300-500 \mathrm{ml}$ of phosphate-buffered saline followed by $500-1000 \mathrm{ml}$ of $10 \%$ buffered formalin. The gyrus containing the penetrations was removed and allowed to sink in $15 \%$ sucrose. Frozen sections were cut $(60 \mu \mathrm{m})$ and stained with thionin or cresyl violet.

Behavioral tasks. To assess the recovery of vision after dark rearing, we used two behavioral tasks as described by Kalil (1978). The visual tracking, or following, task was performed by moving a target within the animal's field of view and scoring whether the animals paid attention to the target and tracked it accurately. The animal was scored as tracking or not tracking by the observer. The visual placing task was carried out by slowly moving the kittens toward the edge of the cage floor and noting whether the animal extended a forepaw toward the surface before tactile contact was made.

\section{Results}

A total of 261 cells were recorded from area 17 of four groups of animals. Out of the total sample of cells recorded, 211 were tested on line and yielded estimates of firing rates and directional selectivity, and 157 of these also gave stable visual responses for long enough to perform the iontophoretic experiments described below. Visual responses in DR animals were weaker than those found in normal kittens of the same age, but a large enough population was sufficiently robust to carry out the experiments described here (see below).

\section{Dark-reared animals}

Effects of $D-A P V$. The NMDA component of the visual response was measured by blocking the receptors with the antagonist D-APV during stimulation of the receptive field (see Fig. 1). The stimulus was a bar of light, tuned to the optimal stimulus conditions for the cell, moving continuously in and out of the cell's receptive field (see Materials and Methods).

A two-factor ANOVA for the effect of D-APV on cells recorded in light-reared (LR) versus DR animals showed that the effect of D-APV was dependent on layer $(p<0.001$, df $=3$ ) and rearing condition $(p<0.001, \mathrm{df}=4)$. There was also an interaction between layer and rearing condition $(p<0.02, \mathrm{df}=$ 12), implying that the sensitivity of the visual response to D-APV was not shifted uniformly in all layers of DR animals (relative to LR animals). The analysis described below and cataloged in Table 1 indicates that the interaction between layer and rearing condition was due to the effect of D-APV being similar in layers II and III of LR and DR animals, but different in layers IV, V, and VI.

Visual responses of layer II/III neurons were substantially reduced by D-APV ejected with $10 \mathrm{nA}$ iontophoretic current in almost all cases. D-APV attenuated the visual responses of all layer II/III cells in DR animals and $84 \%$ of those in LR animals. The extensive overlap in the distribution of visual response reductions in the presence of D-APV (see Fig. 5) implies that the two cell groups behave similarly (see Table 1 for numerical analysis).

The results for cells in deeper layers of the cortex were dependent on rearing condition. In layer IV of LR animals, only $15 \%$ of cells showed any sensitivity to D-APV, compared to $85 \%$ in DR animals of the same age. The average reduction in visual response was significantly greater for layer IV cells in the DR group (see Table 1). Figure 1 shows examples of two cells recorded from layer IV, one in a DR and one in an LR animal. While the visual response was almost abolished by D-APV in the DR case, only spontaneous activity was affected in the LR case. Results for all cells are shown in Figure 5.

The effect of D-APV was also greater in layers V and VI of DR animals compared to controls. In 6-week-old LR animals, the NMDA-component of the visual response was small or absent in layers V and VI, but large in the same layers of DR animals (see Table 1). A brief report of these findings has appeared previously (Fox et al., 1991).

Comparison of the effect of D-APV and $C N Q X$. We found that CNQX reduced visual responses in all cases (31 of 31 ), including those where D-APV had little or no effect (15 of 15). An example is shown in Figure 2 of a cell where D-APV, applied using an ejecting current of $40 \mathrm{nA}$, only succeeded in reducing spontaneous activity, yet CNQX iontophoresed using $10 \mathrm{nA}$ almost abolished the visual response. Unlike D-APV, CNQX had effects in all layers of LR animals. On average, CNQX reduced visual responses to $30 \pm 14 \%$ (mean $\pm \mathrm{SD}$ ) of control levels (Fig. 3). In most cases, CNQX did not completely abolish visual responses. One interpretation is that the remaining response was mediated via a different receptor. Our experiments do not address this issue, however, as we did not increase the "dose" of CNQX in cases where a residual response remained during ejec- 
Control

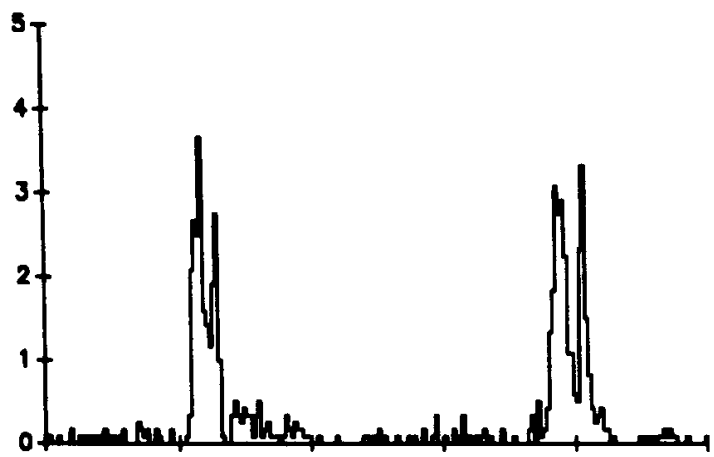

10nA D-APV

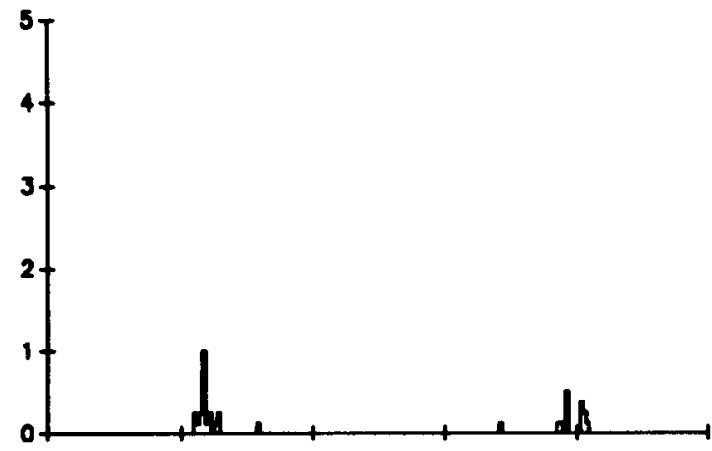

Recovery

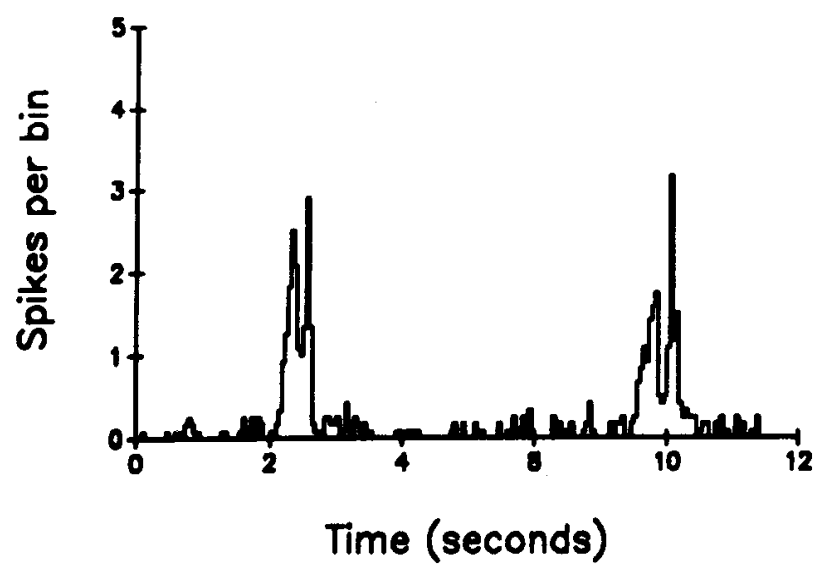

Control

Light-reored

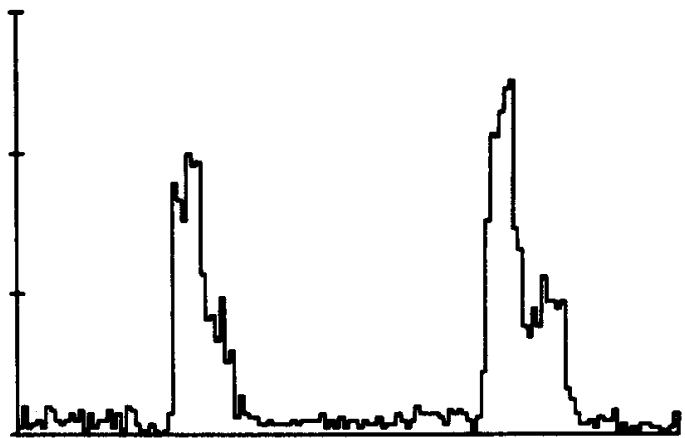

IOnA D-APV

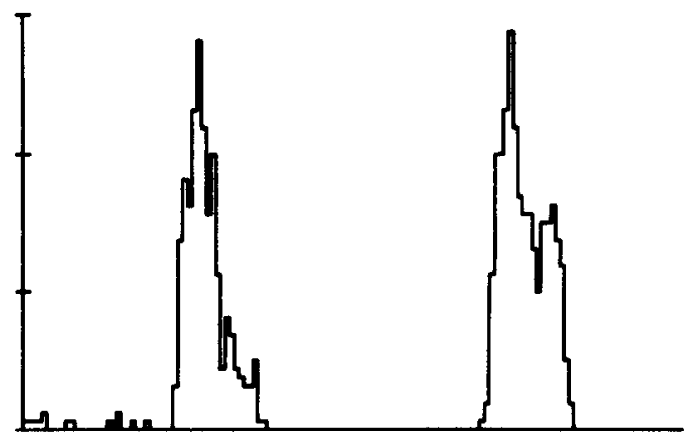

Recovery

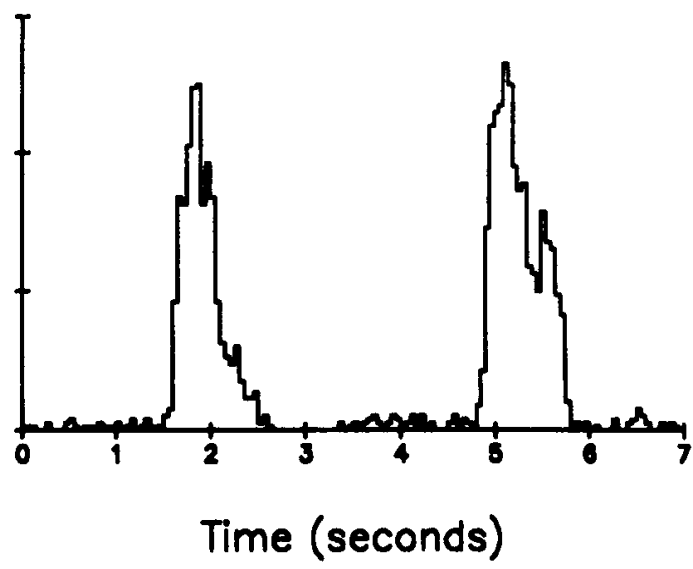

Figure 1. Examples of the effect of D-APV in DR and LR animals. Left column, Peristimulus time histograms for a layer IV cell recorded from an animal dark reared to the day of recording at $47 \mathrm{~d}$. The top trace shows an average of the responses to 20 stimulus presentations. The visual response is almost abolished by D-APV during the second and third minutes of application (11\% of control), during which time eight stimuli are presented (center trace). Recovery occurs to $78 \%$ of control levels within $8 \mathrm{~min}$ (bottom trace). Right column, A layer IV cell recorded from a 49 d-old LR animal. In this casc, the samc procedure of D-APV application fails to reduce the visual response of this cell (106\% of control), though spontaneous activity is affected. Bin width, $50 \mathrm{msec}$. Note time base differs for the two cells.

tion of CNQX. It is quite likely that we did not produce a sufficiently high concentration of CNQX to block non-NMDA receptors completely. Interpreting the effects of higher doses of CNQX would in any case be problematic since this drug can antagonize the glycinc site at NMDA receptors (Yamada et al., 1989) and can also decrease inhibition (Hablitz and Sutor, 1990).

The difference between the effect of CNQX in DR and LR animals was insignificant ( $p>0.5$, $\mathrm{df}=29$, two-tailed $t$ test). For the same cells, the difference between the effect of D-APV in DR and LR animals was highly significant $(p<0.001, \mathrm{df}=$ 29 , two-tailed $t$ test). Results are shown in Figure 3.

The effect of CNQX was not predictive of the effectiveness of D-APV, as shown in Figure 4. The cells are clustered in two places on the $D-\Lambda P V$ axis. Points lying to the right side of the graph are indicative of a lack of effect of D-APV; these points correspond to cells recorded in layers IV, V, and VI of LR animals. The second cluster lying in the middle of the graph (visual responses reduced to $30-60 \%$ of control by D-APV) 

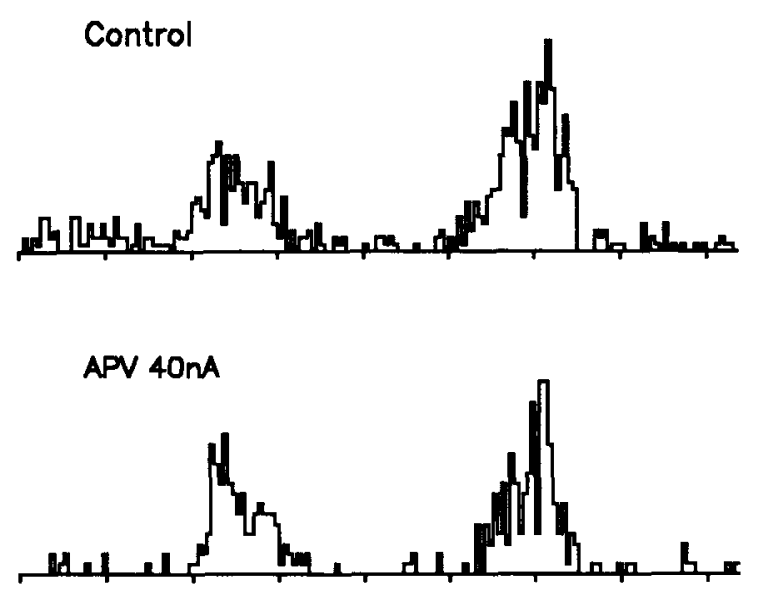

APV 4OnA + CNQX 10nA
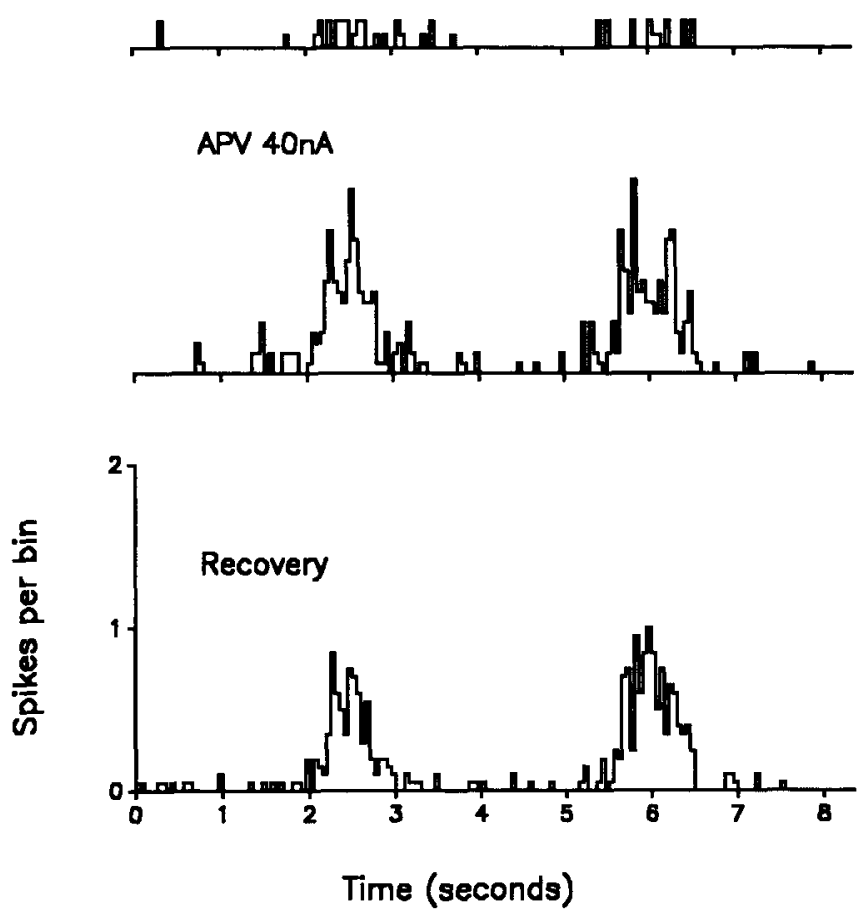

Figure 2. Effect of D-APV and CNQX on visual responses: peristimulus time histogram recorded from a cell located in layer IV of an LR animal. Top trace, Control. Second trace, Application of D-APV using $40 \mathrm{nA}$ ejecting current does not significantly alter the response of this cell (reduction to $86 \%$ of control), but a brief 3 min application of CNQX using $10 \mathrm{nA}$ ejecting current reduces the cell's response to $13 \%$ of control values (center trace). Recovery from the effects of CNQX occurs in the continued presence of D-APV ejection (to $91 \%$ of control values; fourth trace). When D-APV iontophoresis is also terminated, the response remains unaltered (bottom trace). Bin width, $50 \mathrm{msec}$.

represent cells recorded in layers II and III of LR animals and cells recorded in all layers (including layers IV, V, and VI: solid circles) of DR animals. CNQX affected visual responses of all the cells, indicated by the position of their points mainly lying in the lower half of the graph. CNQX reduced visual responses to between $10 \%$ and $60 \%$ of control levels irrespective of the effect of D-APV.

In summary, in situations where CNQX decreased the visual response but D-APV did not, a significant proportion of the synapses activated by the visual stimulus were dominated by non-NMDA conductances; almost all the cells found in layers IV, V, and VI of LR animals, at or beyond 6 weeks of age, fell into this category. In contrast, DR animals appear to have mixed NMDA and non-NMDA receptors at visually driven synapses in all layers.

\section{Late exposure to light}

From the results described above, NMDA-dependent visual responses appear to be downregulated functionally either as a direct or indirect consequence of the animal being reared in the light. To test this idea further, two groups of animals were reared in the dark until they reached 6 weeks of age and were then brought into the light, either for 4 or $10 \mathrm{~d}$, and the NMDA component of the visual response was estimated across a population of cortical cells. Outside the dark-rearing cages, the animals lived in an environment of $14 \mathrm{hr}$ light/10 hr dark.

Effects of $D-A P V$. After 6 weeks of dark rearing, the NMDA component of the visual response comprised a substantial proportion of the total response for most cells, as shown in Figure 5. However, $4 \mathrm{~d}$ exposure to the light after dark rearing was sufficient to reduce the proportion of cells with a significant NMDA component below that encountered in purely DR animals: in layers IV, V, and VI, $40 \%$ of the cells in these lightexposed animals had visual responses that were unaffected by D-APV versus $12.5 \%$ for purely DR animals. The distribution of responses for recordings made during iontophoresis of D-APV is characterized by a very large variance for all layers of cortex in the animals light reared for $4 \mathrm{~d}$. Hence, we encountered cells in layer $\mathrm{V}$ and VI where D-APV reduced the response to $10 \%$ of control and others where D-APV had no measurable effect. Four days of exposure to the light was not sufficient to change the distribution of D-APV sensitivity back to normal levels, so that " 6 week LR" and " $4 \mathrm{~d}$ light exposed" animals were still different ( $p<0.01, \mathrm{df}=4$, two-factor ANOVA).

After $10 \mathrm{~d}$ in the light, the distribution of visual responses under D-APV iontophoresis was similar to that of normal LR animals ( $p>0.7$, two-factor ANOVA). For layer IV, the means $\pm \mathrm{SD}$ were $91 \pm 11 \%$ of control for 6 weeks in the light and $85 \pm 12.5 \%$ of control for $10 \mathrm{~d}$ in the light, which is an insignificant difference $(p>0.2, \mathrm{df}=26, t$ test). For layers $\mathrm{V}$ and VI combined, the means were $85 \pm 17 \%$ for 6 weeks light rearing versus $83 \pm 24 \%$ for $10 \mathrm{~d}$ light exposure, which again is not a significant difference $(p>0.8, \mathrm{df}=16, t$ test $)$.

The data are summarized in Figure 6 for individual layers. Under normal rearing conditions, the NMDA-component of the response decreases between 3 and 6 weeks of age. At 6 weeks, the distribution is indistinguishable from that of adult animals ( $p>0.2, \mathrm{df}=105$, two-tailed $t$ test). Rearing animals in the dark until 6 weeks of age and then introducing them to the light arrests this process by approximately 3 weeks. When the animals are brought into the light, the rate of loss of NMDA receptor function appears, from Figure 6, similar to that seen during normal rearing.

\section{Stimulus response properties}

Firing rate. The qualitative effects of dark rearing on response vigor and receptive field properties have been described before 


\section{CNQX}
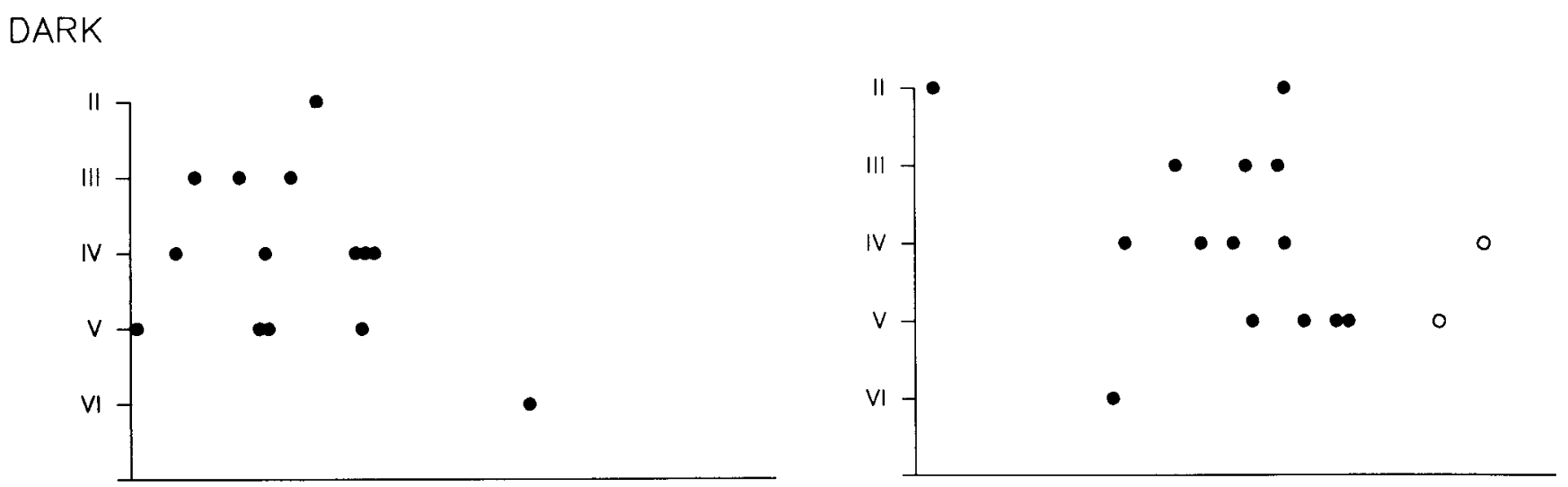
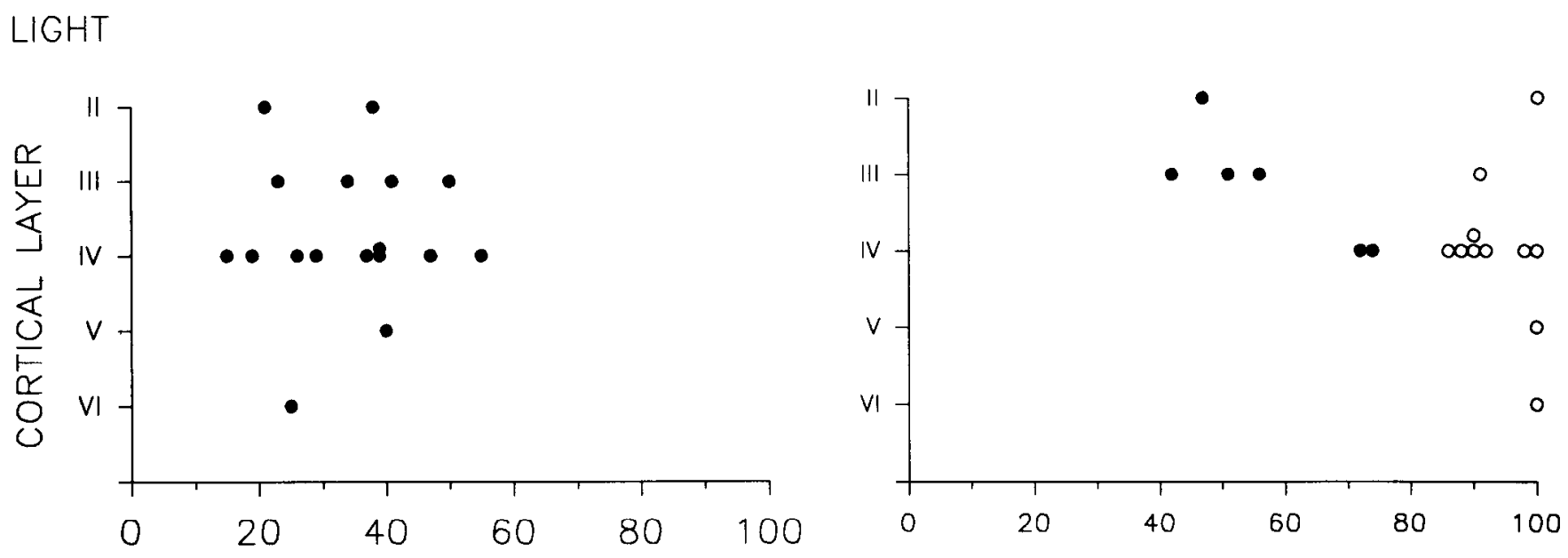

Visual Response During 10nA Antagonist (\% of control).

Figure 3. Summary of the effects of CNQX and D-APV tested on 33 cclls recorded from 6-week-old LR and DR animals. Average firing rate during application of D-APV or CNQX is plotted for each cell as a percentage of the control firing rate according to the layer in which the cell was recorded (see Materials and Methods). Each point represents data from a single cell. Points occurring on the extreme right (100\%) represent cells that showed no change in reply to D-APV. Solid circles represent responses that were significantly changed from control $(p \leq 0.05$, by $t$ test: $\mathrm{d} \Gamma=$ 6 or 7 ); open circles show cases where effects were insignificant $(p \geq 0.1)$. Only 31 cells are shown in the left column, as two cells were affected by but did not recover from CNQX.

(Buisseret and Imbert, 1976; Mower et al., 1981). Our quantitative results on firing rates concur with previous reports in that response firing rates are lower in DR animals (Fig. 7). For DR animals, the mean firing rate $( \pm S D)$ was $9.5 \pm 6$ spikes/sec (median, 7.5) compared with $19 \pm 11$ (median, 15) for LR animals $\left(p<10^{-6}, \mathrm{df}=98\right.$, Mann-Whitney $U$ test). It is perhaps surprising that some cells could be found in DR animals that showed visual responses that werc as good as those recorded in normal LR animals. Approximately $12 \%$ of the cells in DR animals exhibited vigorous responses; that is, their firing rates exceeded the mean firing rates for the population of cells recorded from LR animals. However, one needs to bear in mind that there was a bias in our sampling toward cells with good responses, as only these were useful for the iontophoresis experiments. The real distribution of firing rates for an evenly sampled population of DR cells may therefore be skewed further toward lower values than we show in Figure 7. However, as we sampled cells the same way under all conditions, comparisons between the groups are still valid.
Firing rates did not improve significantly after the 6 week DR animals were returned to the light for $4 \mathrm{~d}$ (mean response, 9.5 \pm 6 for DR vs. $11.5 \pm 7$ for animals introduced to the light). The difference in distributions was not significant using a MannWhitney $U$ test or a $t$ test $(p>0.1$ in both cases, $\mathrm{df}=92)$. A marginal increase in response firing rate occurred after $10 \mathrm{~d}$ exposure to the light, however (mean, 13.1 \pm 9.8 ), though even then not to normal levels (mean, $19 \pm 11$ ). The distribution of firing rates found in animals recorded after $10 \mathrm{~d}$ light exposure was significantly different from both DR and LR groups ( $p<$ $0.01, \mathrm{df}=93$ and $p<0.05, \mathrm{df}=75$, respectively, Mann-Whitney $U$ test).

In summary, $4 \mathrm{~d}$ of rearing in the light did not significantly alter the response firing rates of cells above the level found in DR animals. Ten days of light exposure was sufficient to increase response firing rates, but they were still lower than the levels found in 6-week-old LR kittens.

Direction selectivity. The majority of cells were not selective for particular directions of a moving bar of light in DR animals 


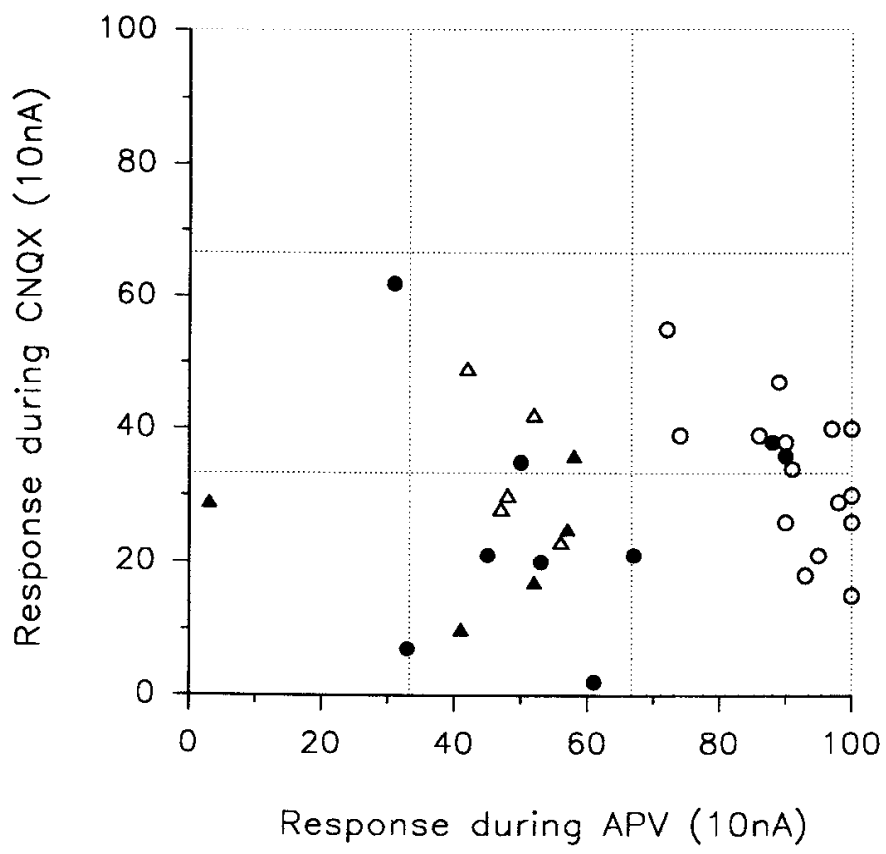

Figure 4. Cross-correlation analysis for the effect of CNQX and D-APV on 34 cells for which both drugs were tested successfully. Circles represent cells located in layers IV, V, and VI, either for DR (solid circles) or LR animals (open circles). Triangles represent data from cells located in layers II/III of DR (solid triangles) and LR animals (open triangles). The effects of D-APV and CNQX are not correlated (see Results for description). Thirty-one cells are common to Figure 3; three others are included from a 7 month LR animal.

(68\%). However, a conspicuous $23 \%$ were direction selective by adult criteria despite never having been exposed to visual stimuli; that is, they were either unidirectional, or bidirectional with no more than $45^{\circ}$ range over which a response could be evoked either side of the optimal direction.

A dramatic improvement in direction selectivity of the overall population occurred after $4 \mathrm{~d}$ of light exposure, as shown in Figure 8 . The number of omnidirectional cells fell from $68 \%$ in DR animals to $35 \%$ in animals light reared for $4 \mathrm{~d}$. The difference in direction selectivity was significant $\left(\chi^{2}=19.47, \mathrm{df}=1, p<\right.$ $0.001)$ comparing relative numbers of omnidirectional and widely tuned (i.e., unselective) cells in DR versus $4 \mathrm{~d}$ light-exposed animals.

As mentioned above, the response firing rates were little changed from levels found in DR animals after $4 \mathrm{~d}$ exposure to the light. Consequently, the population of cells had shifted from poorly responding unselective cells in DR animals to poorly responding selective cells in animals exposed to the light for 4 d. A further $6 \mathrm{~d}$ of light exposure saw no further improvement in direction tuning, however. The proportion of selective cells (uni- + bidirectional) after $10 \mathrm{~d}$ in the light (54\%) was far below that in normal 6-week-old kittens (91\%).

Ocular dominance. After 6 weeks of dark rearing, the ocular dominance histogram was relatively flat with a slight contralateral bias $(\mathrm{BI}=0.473$; WOD $=0.418$ ). This is the state found early in life (Albus and Wolf, 1984). There was no tendency to find monocular cells in layer IV, as occurs for cats that have undergone binocular lid suture (Mower et al., 1981). The ocular dominance histograms showed little difference between the four rearing conditions.

Visuomotor tasks. We tested animals on two behavioral tasks to assess their ability to see; these were the placement task and the tracking task (see Materials and Methods). Six of eight animals failed both tasks on the first day of exposure to the light. Behaviorally, they still used their sense of touch to find their way around their cages. It was only by the third day of light exposure that the kittens showed any sign of using visual information, with five of eight animals performing the placement task. By 4 d of light exposure, however, all animals were showing signs of using their eyes and seven of eight passed the placement task and seven of eight the tracking task (all animals could perform at least one task).

\section{Discussion}

There have been a number of studies examining the effect of dark rearing on development of the cat visual cortex. There is a consensus that dark rearing prevents the normal maturation of receptive field properties in cat visual cortex (Imbert and Buisseret, 1975; Buisseret and Imbert, 1976; Fregnac and Imbert, 1978; Leventhal and Hirsch, 1980; Mower et al., 1981), and while it is true that some neurons display direction selectivity at "first light" (Hubel and Wiesel, 1963), they only comprise a small percentage of cortical cells in visually naive animals (23\% in this study; $23 \%$ in Buisseret and Imbert, $1976 ; 17 \%$ in Cynader et al., 1976). Dark rearing therefore provides a method for separating out aspects of maturation that are dependent on visual experience from those that are not. It has been demonstrated that dark rearing delays the period of geniculocortical afferent segregation (Swindale, 1981, 1988; Mower et al., 1985; Stryker and Harris, 1986), delays the increase in LGN cell size (Kalil, 1978), delays the end of the critical period for monocular deprivation (Cynader and Mitchell, 1980), delays development of orientation and direction selectivity (Imbert and Buisseret, 1975), delays the onset of myelination (Winfield, 1983; Daw, 1986), increases GAP-43 message levels (de la Monte et al., 1989), and decreases ibotenate-stimulated phosphoinositide (PI) turnover (Dudek and Bear, 1989). Finally, binocular lid suture delays synaptogenesis in extragranular layers (Winfield, 1983). Presumably then, maturation of these processes is dependent on visual experience. On the other hand, binocular lid suture has no mcasurable effect on synaptogenesis in layer IV (Winfield, 1983), and dark rearing has no effect on ligand binding to a variety of receptors: adenosine (Aoki, 1985), $\beta$-adrenergic (Wilkinson et al., 1983), benzodiazepine (Schliebs et al., 1986), and $\mathrm{GABA}_{\mathrm{A}}$ (Mower et al., 1988), or on tonic GABAergic inhibition (Tanaka et al., 1987; Tsumoto and Freeman, 1987), or on carbachol-induced PI turnover (Dudek and Bear, 1989). Presumably, these processes are under autonomous genetic control.

In previous work, we have shown that the effect of D-APV in antagonizing visual responses decreases in layers IV, V, and VI during normal development (Fox et al., 1989). By using the technique of dark rearing, we have been able to show in this study that this downregulation of NMDA receptor function is dependent on visual experience, since it does not occur in 6-week-old DR animals until they are brought into the light for 4-10 d.

\section{Interpretation of $D$-APV effects}

Theoretically, there are alternative explanations for our results, but they seem unlikely; diffusion could change in the cortex as a function of age and/or the visually driven receptors could be outside the diffusion range of our electrodes. If extracellular diffusion changes in the cerebral cortex with maturation, due to 


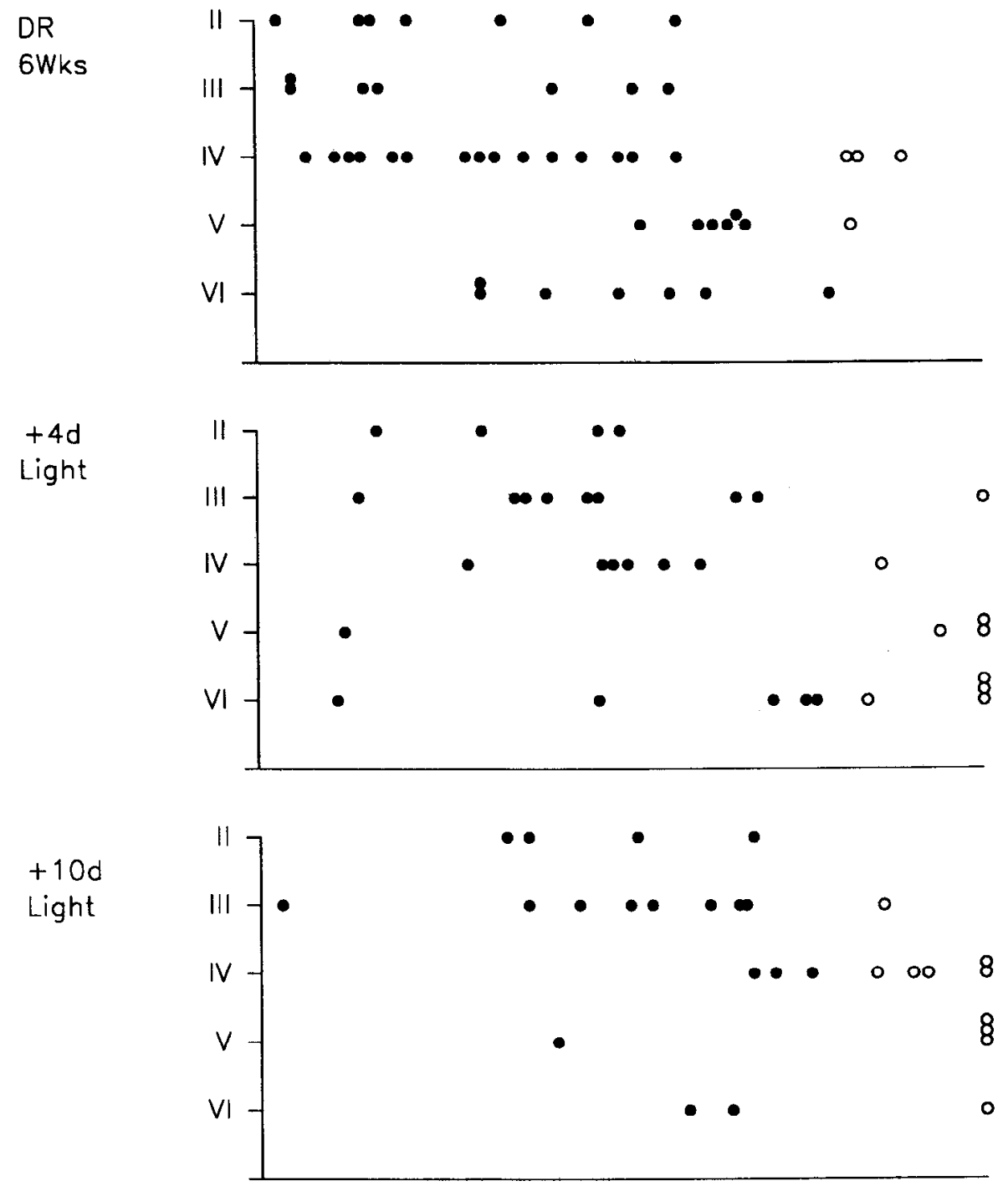

LR

6 Wks

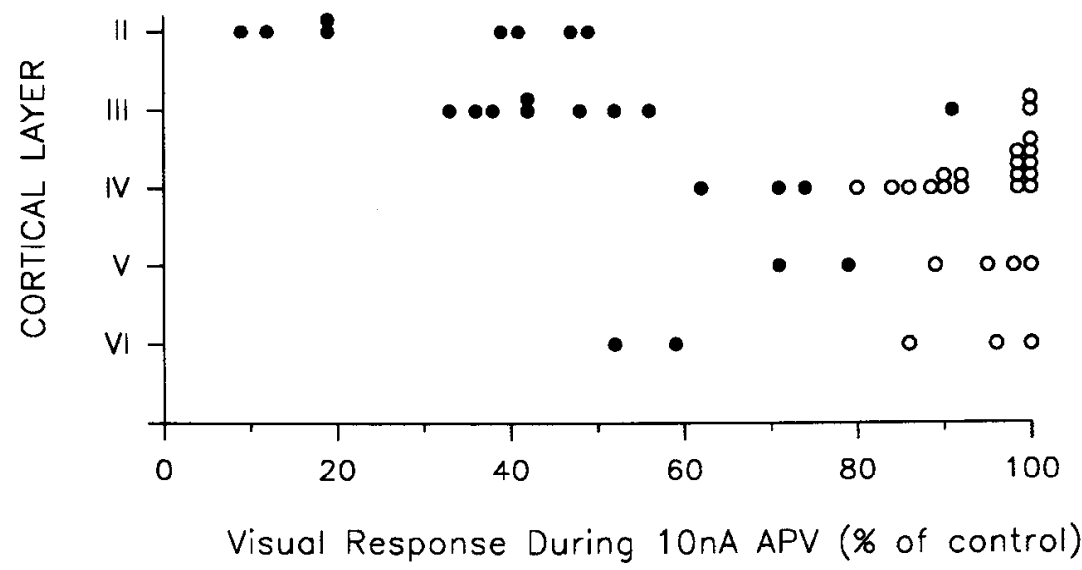

Figure 5. The effect of D-APV on visual responses of cells recorded in DR and LR animals. Top, 46 cells recorded from animals dark reared for 6 weeks; second graph from top, 33 cells recorded from animals dark reared and then introduced to the light for $4 \mathrm{~d}$; third graph from top, 28 cells recorded from animals dark reared for 6 weeks and then light exposed for $10 \mathrm{~d}$; bottom, 50 cells from animals light reared for 6 weeks. There is a gradual shift in the distribution of data points toward the right in layers IV, V, and VI with incrcasing time reared in the light. Open symbols represent cells that did not show a significant change in visual response during administration of D-APV; solid symbols represent significant changes. changes in the extracellular matrix, the effectiveness of our standard iontophoretic assay would also change. However, in order to cxplain fully the results reported here, diffusion would have to remain constant in superficial layers, change in deep layers between the third and sixth weeks but not thereafter, and be altered by dark rearing. We know of no factor that could be changing diffusion in this manner.
The EAA receptors of interest are probably within diffusion range of the electrode. A number of observations suggest that the failure of D-APV to attenuate visual responses in layers IV, $\mathrm{V}$, and VI cannot be accounted for by the visually driven synapses lying beyond the diffusion range of the electrode. We found that CNQX always reduced visual responses, including those unaffected or little affected by D-APV. As there is no reason to 


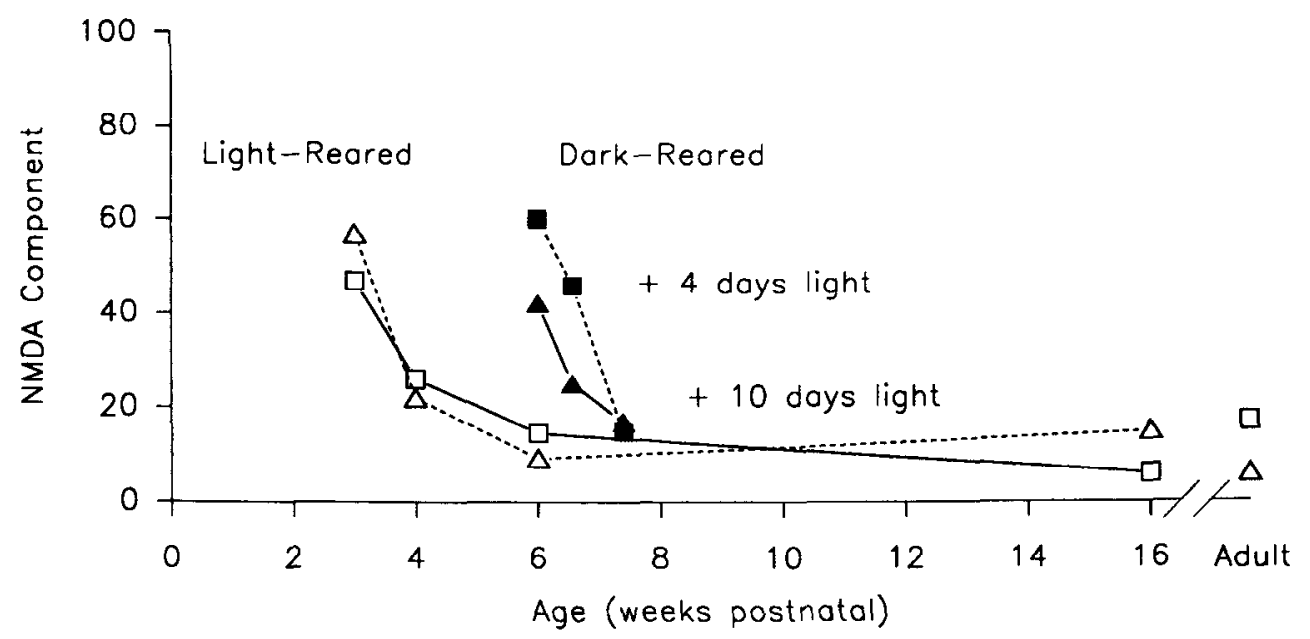

Figure 6. Dependence of the NMDA component of the visual response on time reared in the light. The average size of the NMDA component of the visual response is plotted versus age for cells in different cortical layers. Each data point is an average for cells collected within a particular age group for layer IV cells (squares) and cells in layers V and VI (triangles). The NMDA component of the response decreases between 3 and 6 weeks of age in LR animals (open symbols), but is delayed if animals are reared in the dark for 6 weeks and then introduced to the light for 0 , 4 , and $10 \mathrm{~d}$ (solid symbols). Data are combined from Fox et al. $(1989,1990)$ and this study. The average size of the NMDA component was calculated by averaging the effect of D-APV on single cells (visual response during D-APV $\div$ control visual response) within a particular layer, subtracting the combined average from unity and expressing the result as a percentage.

suppose that the two drugs diffuse differently in the cortex, a significant proportion of the visually driven synapses must lie within diffusion range of D-APV released from the electrode. In cases where D-APV had no demonstrable effect on the cell's visual response, we tested against the possibility that the ejecting current was not carrying D-APV by simultaneously ejecting NMDA, as documented previously (Fox et al., 1989). In these cases, D-APV could be shown to antagonize an NMDA-induced excitation and therefore be present extracellularly in an effective concentration. Finally, it is unlikely that CNQX attenuated the visual response by blocking NMDA receptors in cases where D-APV itself did not decrease the visual response, because D-APV is more potent at NMDA receptors than is CNQX (Honore et al., 1988).

It is possible that we are underestimating the contribution of NMDA receptors to visual responses in layers $\mathrm{V}$ and VI due to the large dendritic arbors of these cells. However, insofar as we can detect a change in the effectiveness of D-APV with age in layers V and VI, at least a subpopulation of synapses must be changing on these cells. It is this population that is affected by dark rearing and under the control of visual experience.

Our methods do not yield information on absolute levels of NMDA receptors in the visual cortex, but only on the proportion of the visual response dependent on NMDA receptor activation. For instance, we would observe the same decrease in NMDA dependence if visually driven non-NMDA receptor conductances increased and NMDA receptor conductances remained the same with development. It is unknown at present whether non-NMDA receptors increase with age in kitten visual cortex, but there is evidence from binding and autoradiographic data that NMDA receptors do decrease with age (Bode-Greuel and Singer, 1989; Gordon et al., 1991; Cynader et al., 1991).

We conclude, therefore, that as excitatory synaptic transmission develops in the visual cortex, there is a gradual shift in the visually driven synapses from mixed NMDA and non-NMDA transmission to predominantly non-NMDA transmission, at least for proximal synapses. This change may involve increases in non-NMDA transmission as well as decreases in NMDA transmission. Such changes are largely restricted to layers IV, $\mathrm{V}$, and VI, while in layers II and III visual responses remain a mixture of NMDA and non-NMDA components into maturity (Fox et al., 1989, 1990). Since the process of NMDA receptor downregulation can be delayed by dark rearing, it is pertinent to examine the alterations in physiological properties that accompany this effect.

\section{Visual responses in dark-reared animals}

A number of studies have shown that neurons have poorly specified receptive fields when animals are reared without visual experience (see above), and our results are in concert on this point. Two former studies have examined the recovery of receptive field properties when DR animals are brought into the light for the first time. In animals dark reared for 5 or 6 weeks and then returned to the light for just $6 \mathrm{hr}$, a dramatic improvement in selectivity was observed (Imbert and Buisseret, 1975; Buisseret et al., 1978). In our experiments, we see an improvement in selectivity for direction tuning after $4 \mathrm{~d}$ in the light. It may be that the change in our animals occurred after just $6 \mathrm{hr}$ too and we discovered this earlier change at $4 \mathrm{~d}$.

After $6 \mathrm{hr}$ in the light and a $12 \mathrm{hr}$ consolidation period in the dark, selectivity was indistinguishable from that seen in normal kittens (Buisseret et al., 1978). However, by our estimation, a large proportion of cortical cells do not reach adult levels of direction selectivity even after $10 \mathrm{~d}$ in the light. Cynader et al. (1976) looked at the recovery of direction selectivity after 1114 months of dark rearing and found that 6-12 months in the light only leads to $50 \%$ of the cells acquiring normal selectivity, which is similar to our figure of $54 \%$. In our study, there was no more increase in selectivity after $10 \mathrm{~d}$ in the light than after $4 \mathrm{~d}$, suggesting a finite capacity for recovery. The fact that $6-$ 12 months in the light after dark rearing does not increase the proportion of selective cells above the $54 \%$ found in our study (Cynader et al., 1976) also supports the idea that DR animals have a finite capacity for recovery.

We found that the trend in recovery of firing rates was similar to the trend in recovery of direction selectivity after dark rearing. 

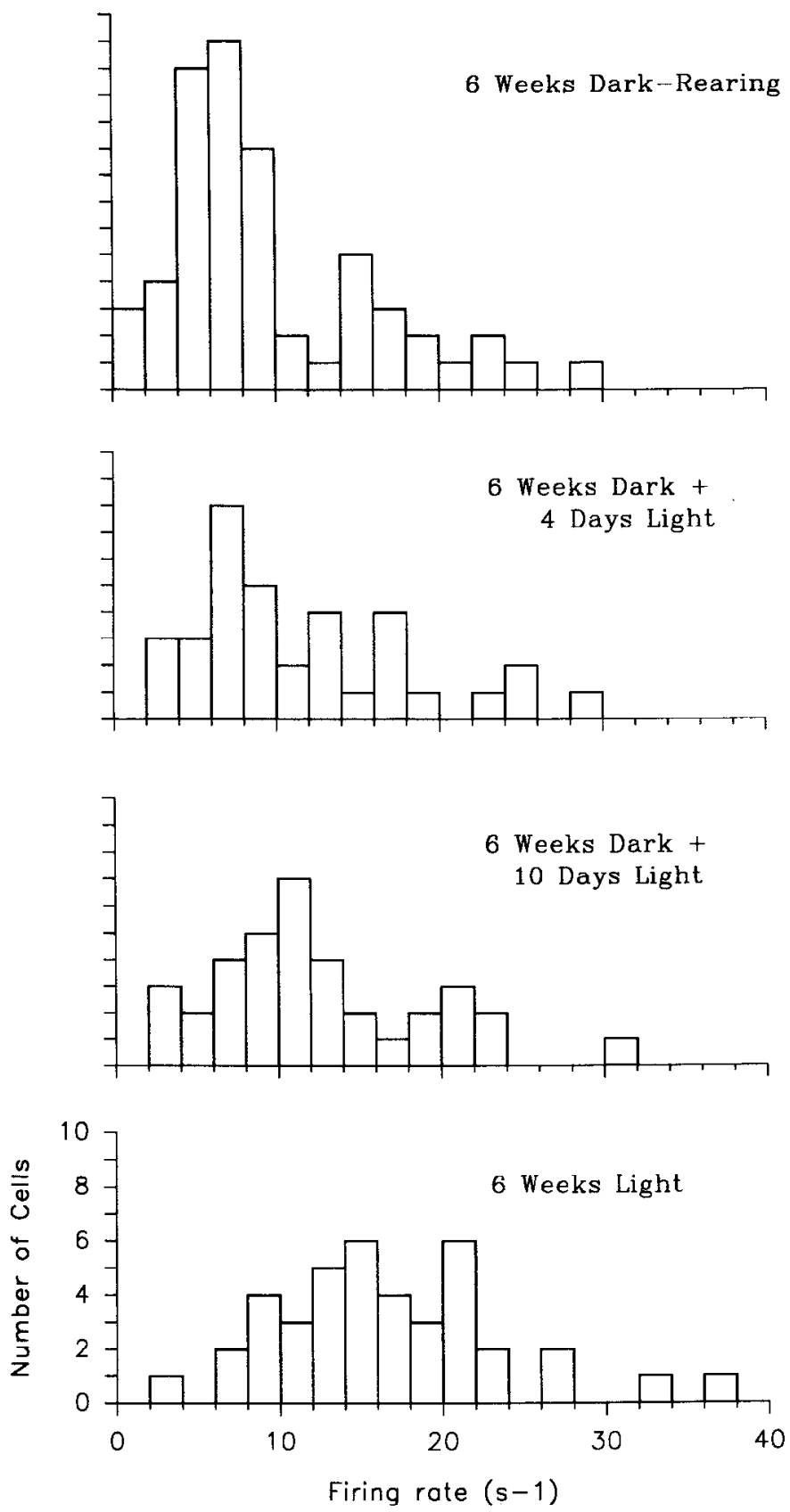

Figure 7. Average firing rates for response to stimulus applied in the optimal direction. Data are shown for four rearing conditions: dark reared for 6 weeks (top graph), dark reared for 6 weeks plus $4 \mathrm{~d}$ light rearing (second graph), 6 weeks dark rearing plus $10 \mathrm{~d}$ light (third graph), and light reared (bottom graph). Notc the gradual increase in firing rates with increasing period spent in the light. The distribution of firing rates still lies short of adult levels after $10 \mathrm{~d}$ in the light.

Firing rates in response to visual stimulation did not reach adult levels after $10 \mathrm{~d}$ in the light. In fact, the only parameter we measured that approached maturity in the $10 \mathrm{~d}$ light-exposed animals was the distribution of cells showing $\mathrm{D}$-APV-sensitive visual responses.

\section{Correlates of $N M D A$ receptor function}

Related but uncorrelated factors. Cells exhibited weaker visual responses in DR animals, but this does not directly explain the differences in NMDA receptor function found between cortical
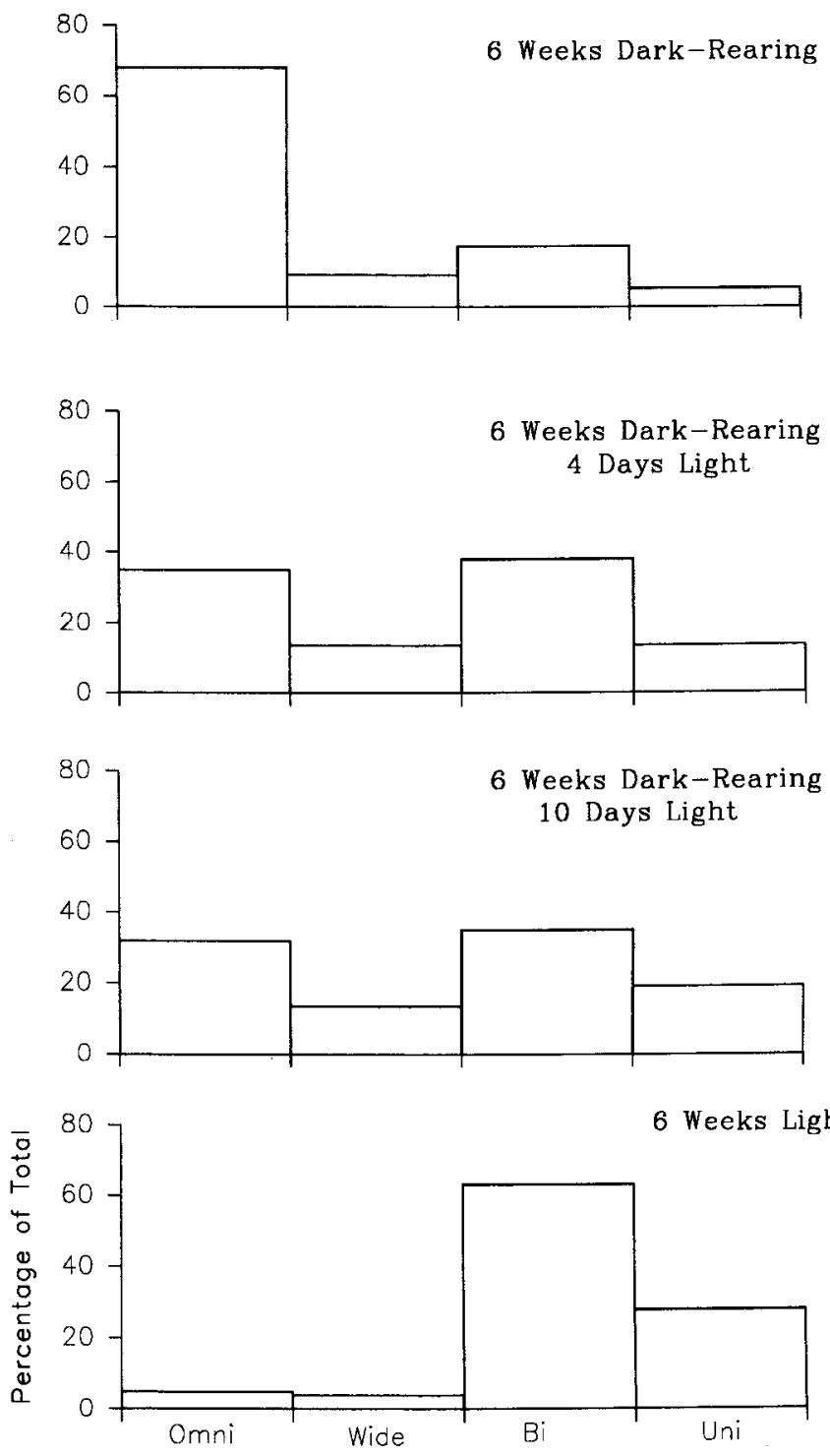

Figure 8. Effect of dark rearing on direction selectivity. See Materials and Methods for classification scheme. Top, Most cells are omnidirectional in purely DR animals. Second graph, After $4 \mathrm{~d}$ in the light many more cells are orientation and direction selective than in purely DR animals. Third graph, Ten days in the light gains no further increase in selectivity over animals reared in the light for $4 \mathrm{~d}$. Bottom graph, In normal LR animals most cells are selective (91\%).

cells in DR and LR animals. In previous studies, we have not found a correlation between the strength of the visual response and the efficacy of D-APV (Fox et al., 1989, 1990). If the strength of response is varied by altering the contrast of the stimulus, D-APV has the same effect on large and small responses (i.e., it reduces responses proportionally by the same amount). If a population of cells, each with different control response firing rates, is examined, the efficacy of D-APV is not correlated with control firing rate. Theoretically, less responsive cells might be expected to activate NMDA currents less well because of the voltage sensitivity of the channel activated by NMDA, and yet the opposite result was obtained in this study; less responsive cells in DR animals exhibited greater NMDA components than those recorded in LR animals.

A lack of receptive field specificity could be indicative of a reduction in inhibitory GABAergic mechanisms (Sillito, 1984). 
Decreased inhibition might thereby result in greater facilitation of NMDA receptor function compared with non-NMDA receptors (Luhman and Prince, 1990), since the channel activated by NMDA in cat cortex is voltage sensitive (Flatman et al., 1986). However, dark rearing appears to increase glutamic acid decarboxylase mRNA in the cortex (Neve and Bear, 1989), and GABAergic mechanisms are not attenuated by dark rearing (Tsumoto and Freeman, 1987). Moreover, dark rearing does not seem to affect the cellular density or location of GABAergic cells or $\mathrm{GABA}_{\mathrm{A}}$ receptors. In view of the lack of cvidence for GABAergic changes, other explanations seem more plausible.

If dendrites, by growing, were to move synapses away from the site of iontophoresis, we would expect to see a developmental relationship between dendritic growth and efficacy of EAA antagonists. An increase in dendritic growth occurs during postnatal maturation of the visual cortex (Meyer and Ferres-Torres, 1984), though layer IV cells are essentially of mature size by 3 weeks, at which time the change in NMDA transmission in this layer has yet to begin. Dendrites also increase in length in layer III between 3 and 5 weeks of age (Zec and Tieman, 1990), but there is no change in the effect of D-APV in this layer. The dendritic growth explanation does not seem plausible either.

Correlated factors. Of all the developmental events that occur in cortex, the decline in NMDA receptors correlates most closely with the period of geniculocortical afferent segregation (Fox et al., 1989). If the decline in NMDA receptors is causally related to segregation, then NMDA receptor distribution should be close to maturity at the same time as the geniculocortical afferent distributions, that is, by approximately 6 weeks (LeVay et al., 1978). This appears to be true (Fox et al., 1991), but testing for a causal relationship between segregation and NMDA receptors is problematic (see introductory remarks). As an alternative strategy, we performed an experiment that might disprove a causal relationship between NMDA receptors and segregation. Rearing animals in the dark is known to delay segregation in cats, and provided it does not continue beyond 8-12 weeks, the system retains an ability to segregate completely on subsequent exposure to the light (Swindale, 1988). If NMDA receptors were to decline to adult values in DR animals by 6 weeks, that is, at an age where complete segregation would still be possible on exposure to the light (Swindale, 1988), NMDA receptors could not be necessary for segregation. As NMDA reccptors were present and driven by visual stimuli in DR animals after 6 weeks of dark rearing, the case for their involvement in segregation is not disproved.

There is a strong parallel between afferent segregation in the tecta of three-eyed frogs and cat visual cortex. In frog tectum, chronic NMDA treatment promotes segregation of afferents emanating from different eyes (Cline et al., 1987, 1990) and decreases the NMDA component of the visual response (Debski et al., 1991). In cat cortex, visual experience promotes geniculocortical afferent segregation and decreases the NMDA component of the visual response during normal development. Since visual stimuli activate NMDA receptors in kitten cortex, NMDA receptor activation may be the common cause of receptor downregulation and segregation in both species.

Correct function of NMDA receptors certainly seems to be necessary for segregation in frog tcctum bccausc blocking NMDA receptors with D-APV or MK-801 leads to desegregation of the afferents from the two eyes (Cline et al., 1987, 1990). Although the effects of D-APV on afferent segregation are unknown in the kitten, D-APV is known to prevent shifts in ocular domi- nance, which partly depend on unequal segregation of input from the two eyes at the ages studied (Bear et al., 1990). D-APV also prevents shrinkage of cells in an area of the LGN topographically related to the cortical area treated with the antagonist in monocularly deprived cats (Bear and Colman, 1990). Since decrease in cell size is thought to be due to the effects of competition between afferents (Guillery, 1972), the lack of decrease in cell size in D-APV-treated animals could again be evidence for effects of D-APV in restricting geniculocortical afferent segregation.

Intracortical axon systems are also segregating in the cortex over the same period as geniculocortical afferents (Calloway and Katz, 1990). The downregulation of NMDA receptors between 3 and 6 weeks of age is therefore correlated with segregation processes in all cortical layers. Downregulation is correlated with segregation of geniculocortical afferents in layers IV and VI and with segregation of intracortical connections within layer $\mathrm{V}$.

\section{Mechanisms for NMDA receptor regulation}

There are a number of mechanisms by which receptors can be regulated from desensitization to endocytotic removal. The functional downregulation seen during normal development, as we report it here, occurs in advance of the decreases reported in binding studies. We note a decrease between 3 and 6 wecks for the NMDA component of the visual response, compared with a decrease starting at 10 weeks and 12 weeks for receptor and channel binding (Bode-Greuel and Singer, 1989; Gordon et al., 1991), respectively. This may reflect a process whereby desensitization precedes physical removal of the receptors, as occurs in other receptor systems (Sibley and Lefkowitz, 1985).

There are a number of ways in which desensitization could occur. It has been proposed that there are two NMDA receptor subtypes (Monaghan et al., 1988), which raises the possibility that during development one subtype is removed or converted to the other form, and this has not yet been studied. The "agonist-preferring sites" seem the physiologically more relevant of the two and, in support of this notion, are distributed in superficial layers of mature animals where NMDA receptors contribute significantly to visual responses at all ages. Another possible mechanism of downregulation could involve one of the many regulation sites on the NMDA receptor, for example, changing its phosphorylation state (MacDonald et al., 1989) or glycine affinity (Kleckner and Dingledine, 1988) and hence its function.

NMDA receptors show rapid developmental downregulation in the cerebellum (Garthwaite et al., 1987) as well as in neocortex (Fox et al., 1989). It is somewhat unusual for receptors to lose function during development: most receptors increase as transmitter systems mature to the adult state (Shaw et al., 1984, 1986; Johnston, 1988). However, it can be demonstrated that in cultured neurons, NMDA receptors are downregulated by glutamate and upregulated by their antagonist ( $O$ 'Brien and Fischbach, 1986). This predicts that if synaptic glutamate release increases during development, it would lead to NMDA receptor downregulation.

\section{Conclusions}

The results of our experiments on dark rearing and late light exposure show that NMDA receptor function in neocortex is regulated by sensory input and is not solely determined by the action of an autonomous "developmental clock." Changes in the NMDA component of the visual response occur too early 
to explain the end of the critical period for ocular dominance plasticity, but do occur during a period of rapid development of neuronal processes and receptive field properties. These results provide evidence of a causal relationship between sensory experience and the function of a receptor that could be involved in determining patterns of connectivity during normal development.

\section{References}

Albus K, Wolf W (1984) Early postnatal development of neuronal function in the kitten's visual cortex: a laminar analysis. J Physiol (Lond) 348:153-185.

Aoki C (1985) Development of the Al adenosine receptors in the visual cortex of cats, dark-reared and normally reared. Dev Brain Res 22:125-133.

Armstrong-James M, Fox K, Millar J (1980) A method for etching the tips of carbon fibre microelectrodes. J Neurosci Methods 2:431432.

Bear MF, Colman H (1990) Binocular competition in the control of geniculate cell size depends upon visual cortical $N$-methyl-D-aspartate receptor activation. Proc Natl Acad Sci USA 87:9246-9249.

Bear MF, Kleinschmidt A, Gu Q, Singer W (1990) Disruption of experience-dependent synaptic modifications in striate cortex by infusion of an NMDA-receptor antagonist. J Neurosci 10:909-925.

Bode-Greuel KM, Singer W (1989) The development of $N$-methyl-Daspartate receptors in cat visual cortex. Dev Brain Res 46:197-204.

Buisseret P, Imbert M (1976) Visual cortical cells: their developmental properties in normal and dark-reared kittens. J Physiol (Lond) 255: 511-525.

Buisseret P, Garey-Bobo E, Imbert M (1978) Ocular motility and recovery of orientational properties of visual cortical neurons in darkreared kittens. Nature 272:816-817.

Calloway EM, Katz LC (1990) Emergence and refinement of clustered horizontal connections in cat striate cortex. J Neurosci 10:1134-1153.

Cline HT, Constantine-Paton M (1990) NMDA-receptor agonist and antagonists alter retinal ganglion cell arbor structure in the developing frog retinotectal projection. J Neurosci 10:1197-1216.

Cline HT, Debski EA, Constantine-Paton M (1987) NMDA-receptor antagonist desegregates eye-specific stripes. Proc Natl Acad Sci USA $84: 4342-4345$.

Cynader M, Mitchell DE (1980) Prolonged sensitivity to monocular deprivation in dark-reared cats. J Neurophysiol 43:1026-1040.

Cynader M, Berman N, Hein A (1976) Recovery of function in cat visual cortex following prolonged deprivation. Exp Brain Res 25:139156.

Cynader M, Liu YL, Jia WG, Booth V, Jacobsen W (1991) NMDAreceptors and L-type calcium channel binding sites re-organize during the critical period for kitten visual cortex plasticity. Soc Neurosci Abstr 17:365.

Daw NW (1986) Effect of dark rearing on development of myelination in cat visual cortex. Soc Neurosci Abstr 12:785.

Daw NW, Fox K (1991) Function of NMDA-receptors in the developing cortex. In: Development of the visual system (Lam DMK, Shatz CJ, eds), pp 243-252. Cambridge, MA: MIT Press.

Debski EA, Cline HT, McDonald IW, Constantine-Paton M (1991) Chronic application of NMDA decreases the NMDA sensitivity of the evoked tectal potential in the frog. J Neurosci 11:2947-2957.

de la Monte SM, Mower GW, Rosen K, Fishman MC (1989) Persistent high level expression of GAP-43 following dark-rearing through the critical period. Soc Neurosci Abstr 15:796.

Dudek SM, Bear MF (1989) A biochemical correlate of the critical period for synaptic modification in the visual cortex. Science 246: 673-675.

Flatman JA, Schwindt PC, Crill WE (1986) The induction and modification of voltage sensitive responses in cat neocortical neurons by $N$-methyl-D-aspartate. Brain Res 363:62 -77.

Fox K, Sato H, Daw N (1989) The location and function of NMDAreceptors in cat and kitten visual cortex. J Neurosci 9:2443-2454.

Fox K, Sato H, Daw NW (1990) The effect of varying stimulus intensity on NMDA-receptor activity in cat visual cortex. J Neurophysiol 64:1413-1428.

Fox K, Daw N, Sato H, Czepita D (1991) Dark-rearing delays the decline in NMDA-receptor efficacy in kitten visual cortex. Nature 350:342-344.
Freeman RD, Bonds AB (1979) Cortical plasticity in monocularly deprived immobilized kittens depends on eye movement. Science 206:1093-1095.

Fregnac Y, Imbert M (1978) Early development of visual cortical cells in normal and dark-reared kittens: relationship between orientation selectivity and ocular dominance. J Physiol (Lond) 278:27-44.

Garthwaite G, Yamini B, Garthwaite J (1987) Selective loss of Purkinje and granule cell responsiveness to $N$-methyl-D-aspartate in rat cerebellum during development. Dev Brain Res 36:288-292.

Gordon B, Daw NW, Parkinson D (1991) The effect of age on binding of MK-801 in the cat visual cortex. Brain Res 62:61-67.

Guillery RW (1972) Binocular competition in the control of geniculate cell growth. J Comp Neurol 144:117-130.

Hablitz JJ, Sutor B (1990) Excitatory postsynaptic potentials in rat neocortical neurons in vitro. III. Effects of a quinoxalinedione nonNMDA-receptor antagonist. J Neurophysiol 64:1282-1290.

Honore T, Davies SN, Drejer J, Fletcher EJ, Jacobsen P, Lodge D, Nielsen FE (1988) Quinoxaline-diones: potent competitive nonNMDA glutamate receptor antagonists. Science 241:701-703.

Hubel DH, Wiesel TN (1963) Receptive fields of cells in striate cortex of young, visually inexperienced kittens. J Neurophysiol 26:994-1002.

Imbert M, Buisseret P (1975) Receptive field characteristics and plastic properties of visual cortical cells in kittens reared with or without visual experience. Exp Brain Res 22:25-36.

Johnston MV (1988) Biochemistry of neurotransmitters in cortical development. In: Cerehral cortex, Vol 7 (Peters A, Jones EG, eds), pp 211-232. New York: Plenum.

Kalil R (1978) Dark-rearing in the cat: effects on visuomotor behavior and cell growth in the dorsal lateral geniculate nucleus. J Comp Neurol 178:451-468.

Kleckner NW, Dingledine R (1988) Requirement for glycine in activation of NMDA-receptors expressed in Xenopus oocytes. Science 241:835-837.

LeVay S, Stryker MP, Shatz CJ (1978) Ocular dominance columns and their development in layer IV of the cat's visual cortex. J Comp Neurol 179:223-244.

Leventhal AG, Hirsch HVB (1980) Receptive field properties of different classes of neurons in visual cortex of normal and dark-reared cats. J Neurophysiol 43:1111-1132.

Luhman HJ, Prince DA (1990) Control of NMDA-receptor mediated activity by GABA-ergic mechanisms in mature and developing rat neocortex. Dev Brain Res 54:287-290.

MacDonald JF, Mody I, Salter MW (1989) Regulation of $N$-methyl$D$-aspartate receptors revealed by intracellular dialysis of murine neurons in culture. J Physiol (Lond) 414:17-34.

Meyer G, Ferres-Torres R (1984) Postnatal maturation of nonpyramidal neurons in the visual cortex of the cat. J Comp Neurol 288: 226-244.

Miller KD, Chapman B, Stryker MP (1989) Visual responses in cat adult visual cortex depend on $N$-methyl-D-aspartate receptors. Proc Natl Acad Sci USA 86:5183-5187.

Mitchell DE, Timney B (1984) Postnatal development of function in the mammalian visual system. In: Handbook of physiology, Sec I, Vol 3 (Darien-Smith I, ed), pp 507-555. Washington, DC: Amer Physiol Soc.

Monaghan DT, Olverman HJ, Nguyen L, Watkins JC, Cotman CW (1988) Two classes of $N$-methyl-D-aspartate recognition sites: differential distribution and differential recognition by glycine. Proc Natl Acad Sci USA 85:9836-9840.

Mower GD, Berry D, Burchfiel JL, Duffy FH (1981) Comparison of the effects of dark-rearing and binocular suture on development and plasticity of cat visual cortex. Brain Res 220:255-267.

Mower GD, Caplan CJ, Christen WG, Duffy FH (1985) Dark rearing prolongs physiological not anatomical plasticity of the cat visual cortex. J Comp Neurol 235:448-466.

Mower GD, Rustad R, Frost WF (1988) Quantitative comparisons of gamma-aminobutyric acid neurons and receptors in the visual cortex of normal and dark-reared cats. J Comp Neurol 272:293-302.

Neve RL, Bear MF (1989) Visual experience regulates gene expression in the developing striate cortex. Proc Natl Acad Sci USA 86:47814784.

O'Brien RJ, Fischbach GD (1986) Modulation of embryonic chick motorneuron glutamate sensitivity by interneurons and agonists. $J$ Neurosci 6:3290-3296.

Reynolds IJ, Bear MF (1991) Effects of age and visual experience on 
$\left[{ }^{3} \mathrm{H}\right]$ MK801 binding to NMDA-receptors in the kitten visual cortex. Exp Brain Res 85:611-615.

Schliebs R, Rothe T, Bigl V (1986) Dark-rearing affects the development of benzodiazepine receptors in the central visual structures of the rat brain. Dev Brain Res 24:179-185.

Shaw C, Wilkinson M, Cynader M, Needler MC, Aoki C, Hall SE (1986) The laminar distributions and postnatal development of neurotransmitter and neuromodulator receptors in cat visual cortex. Brain Res Bull 16:661-671.

Sibley DR, Lefkowitz RJ (1985) Molecular mechanisms of receptor desensitization using the beta-adrenergic receptor coupled adenylate cyclase system as a model. Nature 317:124-129.

Sillito AM (1984) Functional considerations of the operation of GABAergic inhibitory processes in the visual cortex. In: Cerebral cortex, Vol 2 (Jones EG, Peters $\Lambda$, eds), pp 91-117. New York: Plenum.

Stryker MP, Harris WA (1986) Binocular impulse blockade prevents the formation of ocular dominance columns in the cat visual cortex. J Neurosci 6:2117-2133.

Swindale NV (1981) Absence of ocular dominance patches in darkreared cats. Nature 290:332-333.

Swindale NV (1988) Role of visual experience in promoting segre- gation of eye dominance patches in the visual cortex of cat. J Comp Neurol 267:472-488.

Tanaka K, Freeman RD, Ramoa AS (1987) Dark-reared kittens: GABA sensitivity of cells in the visual cortex. Exp Brain Res 65:673-675.

Tsumoto T (1990) Excitatory amino acid transmitters and their receptors in neural circuits of the cerebral neocortex. Neurosci Res 9: 79-102.

Tsumoto T, Freeman RD (1987) Dark-reared cats: responsivitiy of cortical cells influenced pharmacologically by an inhibitory antagonist. Exp Brain Res 65:666-672.

Wilkinson M, Shaw C, Khan I, Cynader M (1983) Ontogenesis of beta-adrenergic binding sites in kitten visual cortex and the effects of visual deprivation. Dev Brain Res 7:349-352.

Winfield DA (1983) The postnatal development of synapses in the different laminae of the visual cortex in the normal kitten and in kittens with eyelid suture. Dev Brain Res 9:155-169.

Yamada KA, Dubinsky JM, Rothman SM (1989) Quantitative physiological characterization of a quinoxalinedione non-NMDA-receptor antagonist. J Neurosci 9:3230-3236.

Zec N, Tieman SB (1990) Dendritic development of layer III pyramidal cells in kitten visual cortex. Soc Neurosci Abstr 16:493. 